\title{
The Language Learning Strategies Used by Students of Merchant Marine Studies Polytechnics Makassar
}

\author{
Nilam Sari Rustam \\ nilamjop@yahoo.co.id
}

\author{
Arifuddin Hamra
}

arifhamra@yahoo.com

Sukardi Weda

sukardiweda@yahoo.com

State University of Makassar, Indonesia

\begin{abstract}
This thesis aims to (1) to investigate the kinds of language learning strategies the merchant marine polytechnics students use in learning English, (2) to investigate the most dominant language learning strategies used by successful and unsuccessful students, and (3) to find out whether or not the successful students employ different language learning strategies from the unsuccessful students. The researcher applied descriptive quantitative method. The population of this research was the students of merchant marine polytechnics of Makassar in academic year 2014/2015. The sample was the fourth semester students of nautical study program, class $\mathrm{C}$ which consisted of 30 students. This research used cluster random sampling technique. This research used 2 kinds of instruments; they were English skill tests and questionnaire. The research data was collected by using English skill tests and SILL questionnaire which were analyzed by descriptive and inferential statistic through SPSS 20.0 for windows program. The result of the descriptive quantitative data showed that (1) the nautical students of merchant marine polytechnics used six kinds of language learning strategies namely metacognitive, compensation, social, memory, cognitive, and affective strategy (2) the most dominantly used language learning strategies among the successful students is metacognitive strategy and the most frequently used language learning strategies among unsuccessful students is social strategy (3) there is a difference in using language learning strategies between successful students and unsuccessful students. The six language learning strategies were employed by the students in learning English. The successful students employed two kinds of language learning strategies; metacognitive and compensation strategy while the unsuccessful students employed four kinds of language learning strategies namely social, memory, cognitive, and affective strategy.
\end{abstract}

Keywords: Language Learning Strategies, Successsful/Unsuccessful Students, Metacognitive, Compensation, Social, Memory, Cognitive, And Affective Strategy

\section{INTRODUCTION}

The success in learning language is influenced by the strategies that the learners used. It seems undeniable that foreign language learners should be equipped with appropriate learning strategies in order to learn target language more effectively and efficiently because language learning is an intentional and strategic effort (Chamot \& O'Mellay, 1990). The usage of 
appropriate learning strategies enables students to take responsibility for their own learning by enhancing learner autonomy, and self-direction. These factors are important because learners need to keep on learning even when they are no longer in a formal classroom setting (Oxford, 1990 p. 42).

Language learning strategy plays a significant role in L2/FL learning, due to the fact that language learning strategies can help learners to facilitate the acquisition, storage, retrieval or use of information and increase selfconfidence (Chang, Ching-Yi \& Liu, Shu-Chen \& Lee, Yi-Nan. 2007). In other word, language learning strategies have an important role in students' learning activities; it can help students to solve their problem in learning a foreign language. In addition, Vann \& Abraham (1990: 177) stated that successful learners used strategies more appropriately in different situations than unsuccessful learners, and used a large range of strategies in language learning more frequently and appropriately.

Therefore, understanding what kinds of language learning strategies (LLS) that the students employ to develop their English proficiency is a crucial importance. Rubin (1975) suggested that knowing more about the strategies "successful learners" select may be helpful. The reason is that unsuccessful learners can adopt those strategies which are regarded as useful and valid by successful learners. In this way, unsuccessful learners can enhance their success record.

Since the early seventies, there has been a great concern in learner characteristics rather than the methods of teaching in the field of second language learning and teaching (Wenden \& Rubin, 1987). Most researchers began to notice that it is a must to identify the characteristics of successful language learners and distinguish the differences of strategy use between successful language learners and unsuccessful ones. Owing to the differences in the frequency and types of strategy use, language learners are divided into various levels of language performers.

It is expected that this way needed in guiding to achieve English proficiency and to fulfil ESP for the students of merchant marine polytechnics especially nautical department. The International Maritime Organization required the students of merchant marine to have a good English proficiency to be capable merchant-marine. The students are required to master English at the $4^{\text {th }}$ semester before board-training for two semesters. During four semesters in merchant marine polytechnics of Makassar, the four of English skills in the acquisition of knowledge were taught in a coherent way. Each of skills; listening, speaking, reading and writing were not taught distinctly or separately, so the students learnt each skills distinctly by self taught. Teaching integrated English skills were given accordance with the needs of English for nautical-deck officer. The students are expected to be able to 
Rustam, Hamra, Weda: The Language Learning Strategies Used by ... $\mid 79$

master English proficiency in celestial \& terrestrial navigation, electronics navigation system, compass \& steering system, ship maneuvering \& handling, position fixing or determination, and also visual communication nautical-deck on board.

The English continuous progression of merchant marine polytechnics in each semester related to the learning that the students use and the method of teacher in teaching especially English for nautical-deck officer. It is supported by Richards and Rogers (2001) who said that the difference of ability in mastering English has relationship with the ability of teacher in conveying of learning, approach, the strategy applied, educational facilities or infrastructure, environment, and motivation of student learning especially English learning strategy.

\section{REVIEW OF LITERATURE}

\section{Learning Strategies}

Oxford (1990) explained that the word 'strategy' comes from the term strategia. It is an ancient Greek term which is mostly used for war that means generalship or the art of war. The word strategies influences to any setting, including education. Oxford (1990:17) also drew learning strategies into two major divisions. They are direct and indirect learning strategy in which each of them has three parts. Furthermore, she mentioned that direct strategy is just like the performer in a stage while indirect strategy is the director of the play. Both performer and director have essential role to reach a successful performance. Performers (direct strategies) are the main actors that directly involved to the target language while the directors (indirect strategies) are indirectly involved to the target language (Husain, 2011:43), but they are important for general management in learning target language. Direct learning strategies consist of memory strategy, cognitive strategy and compensation strategy. Meanwhile, the indirect learning strategies consist of metacognitive strategy, affective strategy and social strategy.

The scope in each of those strategies will be elaborated as follows:

1. Memory Strategies. This is a kind of strategy which is claimed by Oxford as the strategy that has been used for thousands years, it is also sometimes called mnemonic.

2. Cognitive Strategies. Different from the previous strategy, the cognitive strategy had been mentioned by several experts before Oxford did. Cognitive strategies described as the strategies that enable the learners to interact with the material by manipulating it mentally such as grouping the items or taking note on important information to be remembered. 
3. Compensation Strategies. This is valuable for the language learners to solve the knowledge limitation problems both to understand and to produce language.

Another three strategies are classified as indirect strategies that will be elaborated as follows:

1. Metacognitive Strategies. This is the first strategy explained by Oxford as indirect strategy, in which has function for general management of learning. The involved strategies concentrate to centering, arranging, planning and evaluating learning.

2. Affective Strategies. Oxford explained that the affective strategies are essential to control the language learners' learning in the sense of emotions, attitudes, motivations and values.

3. Social Strategies. The last strategy mentioned by Oxford is social strategies. Language and social behavior are two things that cannot be separated, because the actualization of language is in communication.

There are three reasons proposed by Chang (1992) to delineate why language learning strategies are important. First, learners' language learning may become more efficient and effective by using appropriate learning strategies. Learners take certain actions which have been referred to as learning strategies to help learning smoother, faster, and more effective (Oxford, 1990). Second, the use of language learning strategies, according to Wenden's (1987) viewpoint, is to fulfill the goal of facilitating learner autonomy. Since language learning is a lifelong task and learning the language only through teacher' instruction in classroom is not enough. Hence, students should develop their autonomous ability for learning outside the college. Third, language learning strategies are supplementary means to solve the difficulties learners encountered in second language learning. In this way, the process of language learning will be facilitated and improved with the higher frequency of using appropriate learning strategies.

In sum, language learning strategies are the causes and outcomes of successful language learning. Language learning strategies not only help learners to develop autonomy but also enable them to become good language learners and make language learning faster but effective.

\section{Good Language Learner}

The main goal in learning a language is how student can be a good language learner because there is an awareness of learners that learning English is very important thing for us, that's why language learners try to know how to learn a language, not just what to learn. By knowing the characteristics of 
Rustam, Hamra, Weda: The Language Learning Strategies Used by ... $\mid 81$

good language learners can help students increase their language learning efficiency.

Most of early the studies in the field of language learning strategies focused on identifying the characteristics of good language learner. Identifying and discussing the strategies used by good language learners are considered as a good way to make the learners aware of the notion of language learning strategies. Rubin \& Thompson (1982:53-54) mention the following characteristics for good language learners:

1. Good language learners find their own and take charge of their meaning. They determine the methods that are best for them as individual learners. They learn from others and experiment with different methods.

2. Good language learners organize their study of the language and they organize information about the language they study.

3. Good language learners are creative. They understand that language is creative. They experiment with the language and play with grammar, words and sounds.

4. Good language learners make their own opportunities for practicing the language inside and outside of the classroom.

5. Good language learners learn to live with uncertainty by focusing on the meaning of what they can understand, by not getting flustered, and by continuing to talk or listen without necessarily understanding every word.

6. Good language learners use mnemonics and other memory strategies to recall what they are learning.

7. Good language learners make errors work for them and not against them.

8. Good language learners use linguistic knowledge, including knowledge of their first language, in learning a second language.

9. Good language learners use contextual clues to aid their comprehension of the language. They maximize use of all potential contexts around the language attended to for enhancing comprehension.

10. Good language learners learn to make intelligent guesses.

11. Good language learners learn chunks of language as wholes and formalized routines to help them perform beyond their competence. For example, they may learn idioms, proverbs, or other phrases knowing what the whole phrase means without necessarily understanding each individual part.

12. Good language learners learn certain tricks that keep conversation going.

13. Good language learners learn certain production techniques that also fill in the gaps in their own competence. 
14. Good language learners learn different styles of speech or writing to learn to vary their language according to the formality of the situation.

Wenden (1990:174) stated that there are nine characteristics of a good language learner, they are:

1. Good language learners find a style of learning that suits them.

2. Good language learners are actively involved in the language learning process.

3. Good language learners try to figure out how the language works.

4. Good language learners know that language is used to communicate.

5. Good language learners learn to think in the language.

6. Good language learners realize that language learning is not easy.

7. Good language learners have a long term commitment to language learning.

This study concerns about kinds of learning strategies by Oxford (1990) because it elaborates the notion of "strategy" and examines a kind of learning strategies. Successful learners however learn to adopt active strategies of their own, incorporating monitoring behavior into their learning skills. In this research, to investigate the learning strategies of students, SILL (Strategy Inventory for Language Learning) was used. The SILL was designed for students of English as a second language or foreign language. It is divided into six parts; each will tell the kinds of strategies used in learning English. They are Remembering more effectively (Memory strategies), Using all mental processes (Cognitive strategies), Compensating for missing knowledge (Compensation strategies), Organizing and evaluating learning (Metacognitive strategies), Managing your emotions (Affective strategies), and Learning with others (Social strategies).

\section{METHOD}

This research used descriptive quantitative method. This research was employed to investigate about the students' language learning strategies used by the students in learning English. The population of this research was the fourth semester merchant marine students of nautical class-C in Merchant Marine Studies Polytechnics or Politeknik Ilmu Pelayaran (PIP) Makassar in academic year 2014/2015. It consisted of six classes. It consisted of 30 students for each class. The total of the population was 180 students. The researcher used cluster random sampling to select groups. After selecting randomly, the class-C of nautical class was chosen as a sample.

This research was carried out by using English skills tests and a questionnaire survey. The tests were administered to know the students' achievement in learning English for each skill. 
The questionnaire of SILL (Strategy Inventory for Language Learning) developed by Rebecca in Oxford (1990) was used in this research to obtain information and to act as a stimulus for ideas about language learning strategy. The SILL uses a 5-point Likert scale for which the learners were guided to respond to a strategy description, and the criteria used for evaluating the degree of strategy use frequency are: low frequency use (1.0 2.49), moderate frequency use (2.5 -3.49), and high frequency use (3.5 - 5.0).

\section{FINDINGS AND DISCUSSION}

\section{Findings}

\section{Language Learning Strategies Used by the Students}

Based on SILL Questionnaire, there are six kinds of language learning strategies used by the students of merchant marine polytechnics or PIP Makassar in English class. The data shows that each student has different kinds of learning strategies. Data are clearly presented in the 4.1 table:

Table 4.1 The Percentage and Frequency Table of Students' Language Learning Strategies

\begin{tabular}{lcc}
\hline $\begin{array}{c}\text { Language Learning } \\
\text { Strategies }\end{array}$ & Frequency & Percentage \\
\hline Memory & 3 & $10 \%$ \\
Cognitive & 3 & $10 \%$ \\
Compensation & 7 & $23.33 \%$ \\
Metacognitive & 11 & $36.67 \%$ \\
Affective & 2 & $6.67 \%$ \\
Social & 4 & $13.33 \%$ \\
\hline Total & 30 & $100 \%$ \\
\hline
\end{tabular}

Based on the table 4.1, the merchant marine or PIP students of Makassar apply all kinds of Language Learning Strategies. They are Memory Strategy, Cognitive Strategy, Compensation Strategy, Metacognitive Strategy, Affective Strategy, and Social Strategy. Metacognitive Strategy included as the most dominantly used strategies in learning English skill which applied $36.67 \%$ (11 students) among 30 students in nautical class. Compensation Strategy is the second strategy which dominantly used $23.33 \%$ (7 students) in the class. The third dominantly used strategy is Social Strategy which applied by $13.33 \%$ (4 students). These three strategies followed by Memory 
and Cognitive Strategy with 10\% (3 students) for each strategy, and Affective Strategy with $6.67 \%$ (2 students). The SILL questionnaires were analyzed by using a 5-point Likert scale. The learners are guided to respond to a strategy description, and the criteria used for evaluating the degree of strategy use frequency are:

Table 4.2 The Percentage and the Frequency Table of Students' LLS in Likert Scale Classifications

\begin{tabular}{llccc}
\hline \multirow{2}{*}{ No } & Classification & \multirow{2}{*}{ Range } & \multicolumn{2}{c}{ Students Score } \\
\cline { 3 - 5 } & & & Frequency & Percentage \\
\hline 1 & High & $3.5-5.0$ & 16 & $54 \%$ \\
\hline 2 & Average & $2.5-3.49$ & 13 & $44 \%$ \\
\hline 3 & Low & $1.0-2.49$ & 1 & $2 \%$ \\
\hline \multicolumn{2}{l}{ TOTAL } & & 30 & $100 \%$ \\
\hline
\end{tabular}

Based on the table 4.2 above, it can be seen that High classification was used by 16 students with $54 \%$, followed by Average classification was used by 13 students with $44 \%$, and Low classification was used by 1 students with 2 $\%$.

Related to the findings above, the researcher made the strategies in line by concerning on the mean score. The following table is the students' mean score of six strategies:

Table 4.3 The Mean Score of Language Learning Strategies Used by the Students

\begin{tabular}{ccccccc}
\hline \multicolumn{6}{c}{ Memory Cognitive Compensation } & Metacognitive \\
& Strategy & Strategy & Strategy & Strategy & Strategy & Strategy \\
\hline Mean & $\mathbf{3 . 3 2}$ & $\mathbf{3 . 4 2}$ & $\mathbf{3 . 7 3}$ & $\mathbf{3 . 8 1}$ & $\mathbf{3 . 1 5}$ & $\mathbf{3 . 6 5}$ \\
\hline
\end{tabular}

Based on the table 4.3 above, it can be seen that Metacognitive Strategy that was used mostly by the students in the class gained mean score 3.81. It was followed by Compensation Strategy with 3.73 and the third was Social Strategy with 3.65 ; the three learning strategies were in a high category. Meanwhile, the last three learning strategies were in average category in which Cognitive Strategy was 3.42, Memory Strategy with 3.32 and Affective Strategy with 3.15. 


\section{The Most Dominant Language Learning Strategies Used by the Students}

Over 30 students, there are students which are categorized as successful and unsuccessful students in English skill. The scores were classified into four levels as follows:

Table 4.4 The Percentage and the Frequency Table of Successful and Unsuccessful Students

\begin{tabular}{lccccc}
\hline \multirow{2}{*}{ Classification } & \multirow{2}{*}{ Score } & \multicolumn{2}{c}{ Successful } & \multicolumn{2}{c}{ Unsuccessful } \\
\cline { 3 - 6 } & & Frequency & Percentage & Frequency & Percentage \\
\hline & & & & & \\
Very Good & $91-100$ & 8 & 44.44 & 0 & 0 \\
\hline & & & & & \\
Good & $81-90$ & 10 & 55.56 & 0 & 0 \\
\hline & $71-80$ & 0 & 0 & 5 & 41.6 \\
Fair & $<70$ & 0 & 0 & 7 & 58.4 \\
\hline & & & & & \\
Poor & 18 & $100 \%$ & 12 & $100 \%$ \\
\hline Total & &
\end{tabular}

Table 4.4 shows that the successful students were in very good and good category. The aggregate percentage of successful students; $44.44 \%$ (8 students) categorized as very good and good category was $55.56 \%$ (10 students). While in the unsuccessful students, there were $41.6 \%$ (5 students) in fair whereas poor category was $58.4 \%$ (7 students).

It can be concluded that there were 18 students categorized as successful students in English skill and 12 unsuccessful students in English skill. After getting the scores and classification from table 4.4, then the previous obtained data of the students' language learning strategies were divided into the successful and unsuccessful students. Then, the data was classified into the most dominant language learning strategies. 
86 | ELT Worldwide Vol. 2 No. 2 October 2015

The Most Dominant Language Learning Strategies Used by the Successful Students.

Table 4.5 LLS's Used by The Successful Students in English Skill (High Achiever Classification)

\begin{tabular}{|c|c|c|c|c|c|c|c|c|}
\hline \multirow[b]{2}{*}{ No } & \multirow[b]{2}{*}{$\begin{array}{l}\text { Students } \\
\text { Name }\end{array}$} & \multicolumn{6}{|c|}{ Dominant Language Learning Strategies } & \multirow[b]{2}{*}{$\begin{array}{l}\text { Dominant } \\
\text { LLs }\end{array}$} \\
\hline & & $\begin{array}{l}\text { Memory } \\
\text { Strategy }\end{array}$ & $\begin{array}{l}\text { Cognitive } \\
\text { Strategy }\end{array}$ & $\begin{array}{l}\text { Compensati } \\
\text { on Strategy }\end{array}$ & $\begin{array}{l}\text { Metacogniti } \\
\text { ve Strategy }\end{array}$ & $\begin{array}{l}\text { Affective } \\
\text { Strategy }\end{array}$ & $\begin{array}{l}\text { Social } \\
\text { Strategy }\end{array}$ & \\
\hline 1 & $\begin{array}{l}\text { AAG } \\
\text { M }\end{array}$ & 2.6 & 3.2 & 3.8 & 4.8 & 3.5 & 4.3 & 4.8 \\
\hline 2 & AAP & 3.6 & 3.8 & 4.2 & 4.7 & 2.7 & 3.8 & 4.7 \\
\hline 3 & $\mathrm{H}$ & 3.3 & 4.1 & 4.3 & 4.7 & 3.7 & 4.0 & 4.7 \\
\hline 4 & MRP & 3.3 & 3.9 & 4.2 & 4.6 & 3.5 & 4.3 & 4.6 \\
\hline 5 & HS & 2.6 & 2.4 & 3.2 & 4.6 & 3.0 & 4.0 & 4.6 \\
\hline 6 & $\mathrm{BA}$ & 4.2 & 4.2 & 3.8 & 4.6 & 3.3 & 3.8 & 4.6 \\
\hline 7 & $\mathrm{BL}$ & 2.7 & 3.3 & 3.5 & 4.6 & 2.5 & 3.7 & 4.6 \\
\hline 8 & $\begin{array}{l}\text { AFB } \\
M\end{array}$ & 3.2 & 3.8 & 3.8 & 4.3 & 3.0 & 3.5 & 4.3 \\
\hline 9 & IPR & 3.9 & 3.6 & 3.2 & 4.3 & 2.8 & 3.5 & 4.3 \\
\hline 10 & $\mathrm{AU}$ & 3.1 & 2.7 & 3.2 & 4.2 & 3.2 & 3.0 & 4.2 \\
\hline 11 & $\mathrm{IH}$ & 2.9 & 2.8 & 3.2 & 4.2 & 3.8 & 3.7 & 4.2 \\
\hline 12 & IS & 3.8 & 4.2 & 4.8 & 3.7 & 2.7 & 4.0 & 4.8 \\
\hline 13 & $\mathrm{JJ}$ & 3.9 & 3.6 & 4.5 & 3.6 & 3.2 & 4.2 & 4.5 \\
\hline 14 & $\mathrm{FS}$ & 3.8 & 3.1 & 4.3 & 3.4 & 2.8 & 4.2 & 4.3 \\
\hline 15 & HAD & 3.2 & 3.9 & 4.0 & 3.4 & 2.8 & 3.5 & 4.0 \\
\hline 16 & $\mathrm{HM}$ & 3.4 & 3.2 & 4.0 & 3.1 & 3.2 & 3.2 & 4.0 \\
\hline 17 & FR & 3.3 & 3.0 & 4.0 & 3.0 & 3.7 & 3.5 & 4.0 \\
\hline 18 & I & 2.6 & 2.9 & 3.7 & 3.2 & 2.2 & 3.0 & 3.7 \\
\hline
\end{tabular}

Table 4.5 displays that the most dominant used language learning strategies among the successful students was metacognitive strategy and followed by compensation strategy at the second place. There were 11 successful students used metacognitive strategy and 7 successful students used compensation strategy in English skill. 
Rustam, Hamra, Weda: The Language Learning Strategies Used by ... 87

Table 4.6 LLS's Used by Unsuccessful Students in English Skill (Low Achiever Classification)

\begin{tabular}{|c|c|c|c|c|c|c|c|c|}
\hline \multirow{2}{*}{ No } & \multirow{2}{*}{$\begin{array}{l}\text { Students } \\
\text { Name }\end{array}$} & \multicolumn{6}{|c|}{ Dominant Language Learning Strategies } & \multirow[b]{2}{*}{$\begin{array}{l}\text { Dominan } \\
\text { LLs }\end{array}$} \\
\hline & & $\begin{array}{l}\text { Memory } \\
\text { Strategy }\end{array}$ & $\begin{array}{l}\text { Cognitive } \\
\text { Strategy }\end{array}$ & $\begin{array}{l}\text { Compensatior } \\
\text { Strategy }\end{array}$ & $\begin{array}{l}\text { Metacognitive } \\
\text { Strategy }\end{array}$ & $\begin{array}{l}\text { Affective } \\
\text { Strategy }\end{array}$ & $\begin{array}{l}\text { Social } \\
\text { Strategy }\end{array}$ & \\
\hline 1 & $\mathrm{~A}$ & 3.7 & 3.6 & 4.0 & 3.4 & 2.8 & 4.5 & 4.5 \\
\hline 2 & $\mathrm{JA}$ & 4.1 & 3.6 & 4.2 & 4.1 & 3.3 & 4.3 & 4.3 \\
\hline 3 & $\mathrm{~F}$ & 4.0 & 3.8 & 3.8 & 3.8 & 3.2 & 4.3 & 4.3 \\
\hline 4 & IKWS & 3.2 & 2.8 & 3.7 & 3.3 & 3.0 & 3.8 & 3.8 \\
\hline 5 & $\mathrm{~K}$ & 3.7 & 3.0 & 3.7 & 3.2 & 3.5 & 3.2 & 3.7 \\
\hline 6 & IDS & 3.7 & 3.1 & 3.2 & 3.6 & 2.8 & 3.0 & 3.7 \\
\hline 7 & $\mathrm{H}$ & 3.1 & 2.2 & 2.7 & 3.0 & 2.7 & 2.7 & 3.1 \\
\hline 8 & EM & 3.0 & 4.4 & 4.2 & 4.2 & 4.2 & 4.0 & 4.4 \\
\hline 9 & AESN & 3.1 & 3.9 & 2.8 & 3.2 & 2.8 & 3.7 & 3.9 \\
\hline 10 & $\mathrm{AB}$ & 2.2 & 3.9 & 3.5 & 3.6 & 2.7 & 2.8 & 3.9 \\
\hline 11 & $\mathrm{IB}$ & 3.4 & 3.0 & 3.7 & 3.2 & 4.2 & 3.2 & 4.2 \\
\hline 12 & MIRP & 3.2 & 3.6 & 2.7 & 2.9 & 3.7 & 3.0 & 3.7 \\
\hline
\end{tabular}

Based on the table 4.6 above, the unsuccessful students were in social strategy of the 12 students, 4 students chose the strategy, followed by memory strategy; only 3 students chose this strategy. It can be seen also that there were 3 students in cognitive strategy and 2 students in affective strategy. So, it can be concluded that metacognitive strategy is the most dominant language learning strategy used from all the students of nautical class in Merchant Marine Studies Polytechnics or Politeknik Ilmu Pelayaran (PIP) Makassar.

\section{The Differences of LLS Employed by Successful and Unsuccessful Students.}

In order to see whether there are any differences of language learning strategies which are employed by successful and unsuccessful students or not, table 4.7 presents the percentage and frequency table of the successful and unsuccessful students in using different language learning strategies that can be seen in the following tables. 
88 | ELT Worldwide Vol. 2 No. 2 October 2015

Table 4.7 The Percentage \& Frequency Table of the Successful \& Unsuccessful Students in Using Different LLS

\begin{tabular}{|c|c|c|c|c|c|c|c|c|c|c|c|}
\hline \multirow{2}{*}{ Classificatio } & \multirow{2}{*}{ Score } & \multicolumn{2}{|l|}{ LLS } & \multicolumn{2}{|c|}{ Successful } & \multicolumn{2}{|c|}{ LLS } & \multicolumn{4}{|c|}{ unsuccessful } \\
\hline & & Metacogniti & Compensation & $\mathrm{F}$ & $\%$ & Social & Memory & Cognitive & Affective & $\mathrm{F}$ & $\%$ \\
\hline $\begin{array}{l}\text { Very } \\
\text { Good }\end{array}$ & $91-100$ & 5 Students & 3 Students & 8 & 44.44 & 0 Student & 0 Student & 0 Student & 0 Student & 0 & 0 \\
\hline Good & $81-90$ & 6 Students & 4 Students & 10 & 55.56 & 0 Student & 0 Student & 0 Student & 0 Student & 0 & 0 \\
\hline Fair & $71-80$ & 0 Student & 0 Student & 0 & 0 & 1 Student & 2 Students & 2 Students & 0 Students & 5 & 41.6 \\
\hline Poor & $<70$ & 0 Student & 0 Student & 0 & 0 & 3 Students & 1 Student & 1 Student & 2 Students & 7 & 58.4 \\
\hline Total & & Mean Score: & 90.27 & 18 & 100 & Mean Score & e: 69.58 & & & 12 & 100 \\
\hline
\end{tabular}

Based on the table 4.7 above, it can be seen from the successful category that a very good classification was used by $44.44 \%$ ( 8 students) who had two learning strategies which was consisted of 5 students from metacognitive strategy and 3 students from compensation strategy. Meanwhile, there were $55.56 \%$ (10 students) in good classification that involved the same learning strategies with 6 students from metacognitive strategy and 4 students from compensation strategy.

It can be seen also that the unsuccessful category was used by $41.6 \%$ ( 5 students) in fair classification and $58.4 \%$ (7 students) in poor classification. Both classifications were divided into four learning strategies which were consisted of 4 students in social strategy, 3 students in memory and cognitive for each and 2 students in affective strategy. From table 4.7, the mean score of successful students' category was higher than successful students (90.27 > 69.58) where the interval was 20.69. It indicated that the mean score in successful or high achiever students was classified as good, whereas the unsuccessful or low achiever students were categorized as poor.

The matrix distribution in each English skill of the successful or high achiever and unsuccessful or low achiever can be seen in table 4.8. This table shows the most English skill mastered by successful and unsuccessful students that correlated to their language learning strategy. 
Table 4.8 The Matrix Table of Each English Skill with Different LLS

\begin{tabular}{|c|c|c|c|c|c|c|c|}
\hline \multirow{2}{*}{ LLS } & \multicolumn{4}{|c|}{ English Skill } & \multirow{2}{*}{$\begin{array}{c}\text { Category } \\
\text { of Class }\end{array}$} & \multirow{2}{*}{$\begin{array}{c}\text { Number of } \\
\text { Students }\end{array}$} & \multirow{2}{*}{ Percentage } \\
\hline & Listening & Speaking & Reading & Writing & & & \\
\hline Memory & // & 1 & 1 & // & Unsuccessful & 3 Students & 10 \\
\hline Cognitive & 1 & - & - & // & Unsuccessful & 3 Students & 10 \\
\hline Compensation & IIII & $/ /$ & IIII & IIIIII & Successful & 7 Students & 23.33 \\
\hline Metacognitive & IIIII & // & IIIIII & IIIIII & Successful & 11 Students & 36.67 \\
\hline Affective & - & - & 1 & /I & Unsuccessful & 2 Students & 6.67 \\
\hline Social & 1 & 1 & // & III & Unsuccessful & 4 Students & 13.33 \\
\hline
\end{tabular}

Table 4.8 illustrates that the successful students were more dominant in reading and writing skill than other skills. It can be seen that 6 students got a good score for each skill; reading and writing. They used metacognitive learning strategy in studying English. For the students who used compensation strategy were good in writing skill with 6 achievers. Meanwhile, the unsuccessful students were more dominant in writing and listening skill than other skills. The students who used social learning strategy was good in writing skill with 3 achievers and followed by 2 achievers for each learning strategies; memory, cognitive and affective learning strategy. For those who used memory learning strategy not only got a good score in writing but also in listening with 2 achievers.

Based on the table 4.8 above, it can be concluded that the successful students who used metacognitive and compensation strategy were more dominant in reading and writing skill than other skills. Meanwhile, the unsuccessful students who used memory, cognitive and affective learning strategy were more dominant in writing and listening skill than other skills.

In sum, the explanation above that is shown in the following table 4.9 briefly stated that all students both successful and unsuccessful category used different language learning strategies. 
Table 4.9 LLS Used by Successful and Unsuccessful Students

\begin{tabular}{llll}
\hline \multirow{2}{*}{ No. } & LLSs & \multicolumn{2}{c}{ Category of Class } \\
\cline { 3 - 4 } & & $\begin{array}{l}\text { Successful } \\
\text { Students }\end{array}$ & $\begin{array}{l}\text { Unsuccessful } \\
\text { Students }\end{array}$ \\
\hline 1 & Memory Strategies & & $\checkmark$ \\
\hline 2 & Cognitive Strategies & & $\checkmark$ \\
\hline 3 & $\begin{array}{l}\text { Compensation } \\
\text { Strategies }\end{array}$ & $\checkmark$ & \\
\hline 4 & $\begin{array}{l}\text { Metacognitive } \\
\text { Strategies }\end{array}$ & $\checkmark$ & $\checkmark$ \\
\hline 5 & Affective Strategies & & $\checkmark$ \\
\hline 6 & Social Strategies & & \\
\hline
\end{tabular}

Table 4.9 shows six language learning strategies usually employed by the students in English skill. The successful students employed two kinds of language learning strategies namely metacognitive and compensation strategy, while the unsuccessful students employed four kinds of language learning strategies. The four language learning strategies used by the unsuccessful students are memory strategy, cognitive strategy, affective strategy, and social strategy. The information on the table 4.9 shows that successful students use both kinds of direct and indirect strategy while unsuccessful students tended to use indirect strategies and direct strategies more dominant than successful students.

\section{Discussion}

\section{Kinds of Students Language Learning Strategies}

The subjects of this research used metacognitive strategy most dominantly, followed by compensation, social, memory, cognitive, and affective strategy as the last used. This result is in line with Dhanapala's (2007) findings of language learning strategies learners in Japan and Sri Langka with metacognitive strategy ranked the highest. The students' response indicated that the students tended to apply strategies when learning English. It also meant that learning strategies played an important role in their learning English, and they were aware of using them in their process of learning English. 
However, Davis and Abas' in Chen (215:2005) research of Indonesian language faculty with SILL 7.0 revealed that Indonesian language specialist showed high use of metacognitive, social, compensation, cognitive, and memory strategies and medium use of affective strategies. Deneme's (2008) study of Turkish students showed that high use of metacognitive and compensation strategies, and medium use of memory, cognitive, affective and social strategies. As for Saricoban and Saricougla (2008), using the SILL 7.0 with 263 students at preparatory class students at School of Foreign Languages at Erciyes University, found that the strategies used more than the others by the students are metacognitive and compensation strategies, while affective strategies are used the least by them. Those findings are similarly to this finding that the fourth semester merchant marine studies polytechnics or PIP students used metacognitive as the most frequently strategies in English skill and compensation as the second strategy. The third frequently strategy used is social strategy and followed by memory, cognitive and affective strategies.

So, it can be concluded that the merchant marine studies polytechnics or PIP students of Makassar used all language learning strategy which is based on the theory from Deneme (2008) who conducted a research about language learning strategy preference of Turkish students. The researcher found that the participants applied all strategies in learning English skill.

\section{The Most Dominant Language Learning Strategies Used by the Studen.}

The researcher found that successful students used more, varied, and better learning strategies than unsuccessful students. It can be seen from the data gained from the students' English skill test result. Mostly successful students who learn using metacognitive strategy succeed in English skill test. It might happend because merchant marine or PIP students are trained firmly and discipline by focusing on centering, arranging, planning and evaluating the learning particularly in learning English. Meanwhile, the unsuccessful students dominantly used social strategy instead of metacognitive startegy. These findings related to O'Malley et al. (1985) that learners without metacognitive approaches have no direction or ability to monitor their progress, accomplishments, and future learning directions. On the other hand, learners who have developed their metacognitive awareness are likely to become more autonomous language learners (Hauck, 2005). However, Devito (2011) investigated also about social language learning strategies that go hand in hand with communication, but the process of communication is not simple. So, the most dominant language learning strategy here is metacognitive strategy for the successful students and social strategy for the unsuccessful students. 


\section{The Differences of LLS Used by Successful and Unsuccessful Students.}

This research found that successful students used metacognitive strategy as the most dominant in usage, followed by compensation strategy as the second usage. Meanwhile, unsuccessful students used social strategy as the most dominant in usage and followed with memory, cognitive and affective strategy as the least used. The result of this research indicated that there is a significant different in using language learning strategies between successful students and unsuccessful students. The more the learning strategies used, the higher the student performance was. This result is consistent with the results of Simsek and Balaban (2010) indicating that successful students used more, varied, and better learning strategies than unsuccessful students.

The quantitative data showed that successful students who used metacognitive more dominantly succeed in English skill after getting some tests in the form of listening, speaking, reading, and writing. Whereas, the most dominant language learning strategy used by unsuccessful students in English skill was social strategy with the same form of English skill test in successful students. The data obtained that six learning strategies (memory strategies, cognitive strategies, compensation strategies, metacognitive strategies, affective strategies, and social strategies) were used by students. The successful students employed two kinds of language learning strategies namely metacognitive and compensation strategy, while the unsuccessful students employed four kinds of language learning strategies. The four language learning strategies used by the unsuccessful students are memory strategy, cognitive strategy, affective strategy, and social strategy. In this respect, successful students use both kinds of direct and indirect strategy while unsuccessful students tended to use indirect strategies and direct strategies more dominant than successful students.

\section{CONCLUSION AND SUGGESTION}

This chapter presents the conclusion and suggestion based on the findings and discussion of the data analysis.

\section{Conclusion}

Based on the research findings and discussion in the previous chapter, the researcher concludes that:

The students of merchant marine polytechnics or Politeknik Ilmu Pelayaran (PIP) Makassar particularly in nautical class used six kinds of language learning strategies. Metacognitive strategy marked as the most frequently used strategy in English skills followed by compensation, social, memory, cognitive, and affective the least used. The most dominant language learning strategy is Metacognitive strategy for successful students and Social strategy for unsuccessful students. There is a difference in using language learning strategies between successful students and unsuccessful students. 


\section{Suggestion}

Based on the conclusions above, the researcher put forwards some suggestions and recommendations as follows:

It is suggested to the students to use the wide variety of learning strategies in order to obtain their satisfactory learning outcomes. It is advisable for each language lecturer to detect the language learning strategies of their students and help them compensate the missing areas in their strategy preference and use. Since this research only identified the learning strategies of university students, it is suggested for further research should examine what really happens if all students go through strategy training as early as possible in their educational experiences.

\section{REFERENCES}

Chang, S. J. and S. C. H. (1992). Language Learning Motivation and Language Strategies of Taiwanese EFL Students. Washington, DC: Department of Education. (ERIC: Document Reproduction Service No. ED371589).

Chang, Ching-Yi \& Liu, Shu-Chen \& Lee, Yi-Nan. (2007). A Study of Language Learning Strategies Used by College EFL Learners in Taiwan. Mingdao University Journal, Vol. 3/2.

Chen, Yueh-Miao. (2005). The Learning Strategies of Taiwanese University Students: English Majors Versus Non-English Majors and Males Versus Females. Indonesian Journal of English Language Teaching, Vol. 1/no.2.

Deneme, S. (2008). Language Learning Strategy Preferences of Turkish Students.Journal of Language and Linguistic Studies, Vol. 4, No. 2.

Devito, J. A. (2011). Komunikasi Antar Manusia. Pamulang: Karisma Publishing Group.

Hauck, M. (2005). Metacognitive Knowledge, Strategies \& CALL. In J.Egbert \& G. Petrie (eds.), CALL research perspectives. Mahwah, NJ: Lawrence Erlbaum Associates, Pages 65-86.

Husain, D. (2011). Fostering Autonomous Learning Inside and Outside the Classroom in Language Learning. Makassar: Badan Penerbit UNM. 
O’Malley, J. M., Chamot, A. U., Stewner-Manzanares, G., Russo, R., \& Kupper, L. 1985. Learning Strategy Applications With Students of English As a Second Language. TESOL Quarterly, 19, 285-296.

O'Malley, J. M. and Chamot, A. U. (1990). Learning Strategies in Second Language Acquisition. Cambridge: Cambridge University Press.

Oxford, R. L. (1990). Language Learning Strategies: Whatever Teacher Should Know. Boston, MA: Heinle Publishers.

Richards, J. C. and Rodgers, T. S. (2001). Approaches and Methods in Language Teaching. Cambridge: Cambridge University Press.

Rubin. J. (1987). Learner Strategies: Theoretical Assumptions, Research History and Typology. In A. L. Wenden \& J. Rubin (Eds.), Learner Strategies in Language Learning (pp.15-30). Englewood Cliffs, NJ: Prentice-Hall.

Rubin. J. (1975). What the "Good Language Learner" Can Teach Us. TESOL Quarterly, 9, 41-50.

Rubin, J., and Thompson, I. (1982). How to be a More Successful Language Learner. Boston: Heinle \& Heinle.

Saricoban, A., and Saricaouglu, A. (2008). The Effects of the Relationship Between Learning and Teaching Strategies on Academic Achievement. Novitas-Royal.Vol.: 2 (2), (pp. 162-175).

Simsek, Ali., and Blaban, J. (2010). Learning Strategies of Successful and Unsuccesful University Students.Contemporary Educational Technology. Anadolu University, Turkey, 1(1), (pp. 36-45).

Vann, R. J. and Abraham, R. G. (1990). Strategies of Unsuccessful Language Learners. TESOL Quarterly, 24, (pp. 177-198).

Wenden, A. 1990 Helping Language Learners Think about Learning' in Currents of Change in English Language Teaching.By Rossner and Bolitho (p.174).

Wenden, A. L. 1987. Conceptual Background and Utility. In A. L. Wenden \& J. Rubin (Eds.), Learner Strategies in Language Learning(pp. 3-13). Englewood Cliffs, NJ: Prentice-Hall. 